\title{
IAMJ
}

INTERNATIONAL

AYURVEDIC

MEDICAL JOURNAL

ISSN: 2320-5091

Impact Factor: 6.719

\section{A SCIENTIFIC DRUG REVIEW ON PUNARNAVA MANDUR}

\section{Chhaya Gupta, ${ }^{1}$ Sushma Tiwari ${ }^{2 *}$}

${ }^{1}$ Associate Professor, Department of Rasa Rashtra and Bhaishajyakalpana, G.S. Ayurvedic and Medical College, Pilkhuwa, Hapud, Uttar Pradesh, India

${ }^{2 *}$ Assistant Professor, Department of Kriya Sharir, SLBSS Ayurvedic College \& Hospital, Handia, Prayagraj,

Uttar Pradesh, India.

Corresponding Author:sushmatiwari5@gmail.com

https://doi.org/10.46607/iamj2309112021

(Published Online: November 2021)

Open Access

(C) International Ayurvedic Medical Journal, India

Article Received:17/10//2021 - Peer Reviewed: 31/10/2021 - Accepted for Publication: 06/17/2021

\section{Check for updates}

\section{ABSTRACT}

Punarnava Mandura a classical Herbo mineral formulation is available on the market either in tablet form or in Churna form and is frequently used for Anemia, Low Platelet count, Low RBC count, swelling around Joints, Generalized Swelling, Gout and other end toxins accumulation. It is also a diuretic and is useful in renal disorders. In renal failure, it is used with Mutrakrichantak Churna for getting good results. Used with it. This medicine is more commonly used in North Indian Ayurvedic practice. Clinical research involves investigating proposed medical treatments, assessing the relative benefits of competing therapies, and establishing optimal treatment combinations. It is the most fruitful line of approach for methods of diagnosis and treatment as described in Ayurvedic literature. Anaemia is the most common indicator used to screen for iron deficiency, the terms anaemia, iron deficiency, Pandu roga is known since Vedic period and Iron preparations for the treatment of Pandu Roga has also been well known since ancient times. Punarnava as name designates regeneration; it may help to decrease, the work of Kidneys as it has Mutral properties.

Keywords: Punarnava Mandur, herbomineral, Anemia. 


\section{INTRODUCTION}

Mainly Ayurveda makes use of Yuktivyapasraya Chikitsa. Acharya Charaka says that the art of prescription depends on knowledge of dosage form and time, and this art, in turn, depends on success, hence the skillful physician stands ever superior to those possessing merely theoretical knowledge of drugs Oushadha jnana is included in the very basic trisootra of Ayurveda. Ayurveda is the science of Hetu (causes), Linga (signs and symptoms) and Oushadha (medication), the supreme refuge of both Swastha and Athura (healthy and ailing), Shaswatha (eternal) and Punya (holy). Acharya Charaka defines Dravya as the one which is the Ashraya (substratum) of Kar$m a$ (action) and Guna (qualities) and is the Samavayi Karana (co-existent) cause. Punarnava Mandura a classical herbomineral formulation is available in the market either in tablet form or in churna forms and is frequently used for Anemia and other disorders.

Therapeutic Indication: Prepared PunarnavaMandura is used in Pandu, Sotha, Udara roga, Anaha, Sula, Arsa, Krimi and GulmaVyadhi. Dose is250-500 mg once or twice a day with suitable Anupana, Honey, Lukewarm water, Takra etc. after food or as directed by physician.

Punarnava Mandura has described by Bhava Prakashin Pandu-Kamala-halimak Rogaadhikara. Charaka Samhita Acharya Charaka has described Punarnava Mandura in Pandu Roga Chikitsaadhyayandi in this text Suddha Mandura Churna is taken in place of Mandura Bhasma. It is indicated with Takra in Pandu Roga, Pliha Roga, Bhaishajya Ratnavali Brihada Rasa Raja Sundar Astanga Samgraha, Abhinava Chintamani has described Punarnava mandura in Pandurogadhikara. In Rasa Kamdhenu, Punarnava Mandura has described inShuladhikara and total 6 ingredients have taken. Only Punarnava and Mandura are the same out of 21 ingredients described in almost all classics. This is indicated for Tridoshaja Parinama Sula. Vangasen Samhita or Chikitsasara Samgraha has described Punarnava Mandura in Parinama Shula Rogadhikara. Here almost the same ingredients are taken as men- tioned in Charaka Samhita or Bhaishajya Ratnavali except for Dantimula and Indrayava.

Description according to the composition of Punarnava Mandura:

\section{PUNARNAVA}

Botanical Name: Boerhaavia diffusa

Family: Nyctaginaceae

Description: Consists of dried, matured whole plant, trailing herb found throughout India and

collected after the rainy season, the herb is diffusely branched with stout rootstock and many long slender, prostrate or ascending branches. Alkaloid is punarnavine.

Properties and Action: Rasa is Madhura, Tikta, $\mathrm{Ka}$ saya, GunaUsna, vipaka, madhura andkarma isAnulomana, Sothahara, Kaphaghna, Dipana, Vatakara, Pittahara.

Important Formulations- Punarnavastaka Kwatha, Churna, Punarnavasava, Punarnavadi Mandura, Sukumara Ghrta, Sothaghna Lepa.

Therapeutic uses- Sotha, Pandu

\section{TRIVRIT}

Botanical Name: Operculina turpethum

Family: Convolvulaceae

Description: It consists of dried root of the plant, a large perennial twiner with milky juice and fleshy roots found growing nearly throughout the country, ascending to $900 \mathrm{~m}$.

Properties and Action: Rasaare Madhura, Katu, Tikta, Kasaya, Guna are Ruksa, Laghu and Tiksna, Virya is Usna, Vipaka is Katu, Kaphapittahara, Sukhavirecanaka, Pittahara, Jwaraharaof Trivrit.

Important Formulations: Hrdyavirecana Leha, Aswagandharista, AvipattikaraCurna and ManibhadraGuda.

Therapeutic UsesMalabandha, Gulma, Udara Roga, Jwara, Sopha, Pandu, Pliha, Vrana, Krmi,

Kustha, Kandu.

\section{SHUNTHI}

Botanical Name: Zingiber officinale.

Family: Zingiberaceae

Description: Consists of the dried rhizome of Zingiber officinale Roxb. (Fam. Zinglberaceae), Widely 
cultivated in India, rhizomes dug in JanuaryFebruary, buds and roots removed, soakedOvernightin water, decorticated, and sometimes treated with lime and dried.

Constituents: Essential oil, pungent constituents (gingerol and shogaol), resinous matter and starch.

Properties and Action: Rasa is Katu, Guna are Laghu, Snigdha, Viryais Usnaand Vipaka, Madhuraand karmas (action) are Anulomana, Dipana, Hridya, Pachana, Vatakaphapaha, Amadoshahara

Important Formulations: Saubhagyasunthi, Trikauchurna, SaubhagyaVati, VaisvanaraChurna.

Therapeutic Uses - Agnimandya, Svasa, Adhmana, Amavata, Pandu, Udararoga

\section{VIDANG}

Botanical name: Embelia Ribes

Family: Myrsinaceae

Description: Consists of dried mature fruits of Embelia ribes, large scandent shrub with long slender, flexible branches, distributed throughout hilly parts of India up to $1600 \mathrm{~m}$.

Properties and Action: Rasa are Katu, Tikta, Virya is UsnaLaghu, Ruksa, Tiksna, Virya is Ushna, Vipaka is Katu, and karma are Anulomana, Dipana, Krminasana, Vatakaphapaha Important formulations are Vidangarista, VidangaLauha, VidangadiLauha and therapeutic uses are Sula, Krmiroga, Udararoga, Adhmana.

\section{CHITRAKA}

Botanical name: Plumbagozeylanica

Family: Plumbaginaceae

Description: Citraka consists of the dried mature root of Plumbago zeylanica, a large perennialsubscandent shrub, found throughout India in wile state and important constituent is Plumbagin.

Properties and Action: Rasa is Katu, Guna are Laghu, Ruksa, Tiksna, Virya is Usna, Vipaka is KatuandKarma are Sothahara, Dipana, Grahi, Pachana, Kaphavatahara, Arsohara, Sulahara.

Important Formulations- Citrakadi Vati, Citrakaharitaki, Citrakadichurnra

Therapeutic Uses- Agnimandya, Grahani Roga, Arsa, Udara sula, Gudasotha

\section{DARUHARIDRA (Stem)}

Botanical Name: Berberis aristata

Family: Berberidaceae

Description: Consists of the dried stem of Berberis aristata an erect, spinous, deciduous shrub, usually, 1.8-3.6 $\mathrm{m}$ in height found in the Himalayan ranges at an elevation of $1000-3000 \mathrm{~m}$, and in the Nilgiri hills in South India.

Properties and Action Rasa isTikta, Guna is Ruksa, Virya is Usna, Vipaka isKatu, andKarma are StanyaSodhana, StanyaDosahara, Dosa Pachana. Important Formulations: BhrangarajaTaila, Asvagandhadyarista, Khadiradi Gutika,

Khadirarista, Jatyadi Taila, Triphala Ghrita.

Therapeutic Uses: Kandu, Medoroga, Mukharoga, Vrana, Amatisara, Urustambha, Kapharoga, Karnaroga, Netraroga, Meha.

\section{BIBHÌTAKA}

Botanical name: Terntinaliabelerica

Family: Combretaceae

Description: Bibhitaka consists of a pericarp of dried ripe fruits of Terntinaliabelerica, a large deciduous tree, $10-12 \mathrm{~m}$ or more high, commonly found in plains and forests up to $900 \mathrm{~m}$

Constituents- Gallic acid, tannic acid and glycosides. Properties and Action: Rasa isKasaya, guna areLaghu, Ruksa, ViryaisUsna, Vipaka is Madhura, and Karma are Chakshusya, Kesya, Kaphapittajit, Bhedaka, Krminasaana, Kasahara.

Important Formulations: TriphalaChurna, TriphaladiTaila, Lavangadi Vati.

Therapeutic Uses: Chardi, Kasa, Krmiroga, Vibandha, Svarabheda, Netraroga.

\section{AMALAKI}

Botanical Name: Emblica Officinalis

Family: Euphorbiaceae

Description: Consists of the pericarp of dried mature fruits of Gaertn. Mostly collected in winter season after-ripening and in Kashmir in summer, a small or medium-sized tree, found both in natural state in mixed deciduous forests of the country ascending to $1300 \mathrm{~m}$ on hills; cultivated in gardens, home yards or grown as a roadside tree. 
Properties and Action: Rasaare Madhura, Amla, Katu, Tikta, KashsyaGuna is Laghu, RuksaViryais Shita(cold), Vipaka is Madhura and Karmaare Chakshusaya, Rasayana, Tridosajit, Vrsya

Important Formulations: Cyavanaprasa, DhatriLauha, DhatryadiGhrta, TriphalaChurna.

Therapeutic Uses: Raktapitta, Amlapitta, Premeha, Daha.

\section{DANTI}

Botanical Name: Baliospermummontanum

Family: Euphorbiaceae

Description: It consists of dried root, a leafy undershrub, distributed in the outer range of the Himalayas from Kashmir to Assam and in moist deciduous forests elsewhere in India. Constituents- B-Sitosterol and Triterpenoids, Resinous Glycosides, Phorbol Esters.

Properties and Action: Rasa is Katu, Gunaare Tiksna, Sara, Laghu, Virya is Usna, Vipaka isKatu, Karma are Kaphahara, Raktadosahara, Vidahara, Dipana, Rocaka, Sodhaka, Vikasi.

Important Formulations: Dantyarista, PunarnavaMandura, Abhyarista, Kankayana Gutika, Dantiharitaki, KalyanakaKsara, KaisoreGuggule.

Therapeutic Uses: Tvakadosa, Daha, Sotha, Udarroga, Sularoga, Krimi, Arsa, Asmari, Kandu, Kustha, Vrana, Pliha Vriddhi, Gulma, Kamala.

\section{MUSTA}

Botanical Name: Cyperus rotundus

Description: It consists of dried rhizome of Cyperus rotundus, occurring throughout the country, common in waste grounds, gardens and roadsides, up to an elevation of $1800 \mathrm{~m}$.

Properties and Action: Rasa are Tikta, Katu, Kasaya, GunaareLaghu, Ruksa, Virya is Shita, Vipaka is Katu Karma arePittakaphahara, Sthoulyahara, Sothahara, Dipana, Pacana, Grahi, Trsnanigrahana, Krmighna, Tvakadosahara, Jwaraghna, Visaghna.

Important Formulations: Musakarista, Mustakadikwatha, Asokarista, Mustakadi Curna, MustakadiLehya.

Therapeutic Uses Agnimandhya, Ajerna, Trsna, Sangrahani, Swasa, Kasa, Mutrakrcchra,
Vamana, Stanyavikara, Sutikaroga, Atisara, Amavata, Krimiroga.

\section{MARICA}

Botanical Name: Piper nigrum

Family: Piperaceae

Description: Maricha consist of fully mature dried fruit of piper nigrum, a climber, cultivated from Konkan Southwards, especially in North Konkan Kerala, and in Assam; Depending upon climatic conditions fruits ripen from December to March, fruits harvested from December to April.

Properties and Action: Rasa are Tikta, Katu, Gunaare Laghu, Ruksa, Tiksna, ViryaisUsna, Vipaka is Katu and Karma are Slesmahara, Pittakara, Kaphavatajit Vatahara, Chedana, Dipana, Ruchya, Jantunasana, Medohara, Chedi, Hrdroga, Vataroga

Therapeutic Uses: Swasa, Kasa, Krimiroga.

\section{PIPPALI}

Botanical Name: Piper longum

Family : Piperaceae

Description: Pippali consists of dried, immature, catkin-like fruits with bracts of Piper longum Linn. (Fam. Piperaceae), a slender, aromatic climber with perennial woody roots, occurring in hotter parts of India from the central Himalayas to Assam up to lower hills of West Bengal and evergreen forests of Western ghats as wild, and cultivated in Northeast and many parts of the South.

Properties and Action: Rasa are Madhura, Katu, Tikta, Gunaare Laghu (Light), Snigdha, Viryais Anusna, Vipaka is Madhura and Karma are Dipana, Hrdya, Kaphahara, Rucya, Tridosahara, Vatahara, Vrsya, Rasayana, Rechana.

Important Formulations: Amrtarista, Ayasakrti, Cyavanaprasa Avaleha, Gudapippali, Asvagandhadyarista, Kumaryasava, Candanasava, Siva Gutika, Kaisora Guggulu.

Therapeutic Uses Swasa (Dyspnea), Kasa (cough), Gulma, Hikka, Krmi, Ksaya, Kustha, Pliha Roga, Prameha, Sula (Pain), Trsna, Udara Roga, Ama Vata (Rheumatoid Arthritis.), Amadosa, Jwara (Fever).

KATUKA

Botanical Name: Picrorhizakurroa

Family: Scrophulariaceae 
Constituents- Glucoside (Picrorhizin).

Properties and Action: Rasa is Katu, Tikta, Gunais Laghu, Viryais Usna Vipaka is Katu Karma are Hrdya, Pittahara, Depaniya, Bhediniya, Jvarahara.

Therapeutic Use: Swasa, Daha, Jwara, Kamala, Kustha, Visamajwara, Arochaka.

DEVADARU (Heart Wood)

Botanical Name: Cedrus deodara

Family: Pinaceae

Description: Devadaru consists of dried heartwood of Cedrus deodara, a very large and tall ever green tree, up to $75 \mathrm{~m}$ in height and ranging from 2.4 to 3.6 $\mathrm{m}$ in girth, occasionally even up to13.5 $\mathrm{m}$ in girth, found in Northwestern Himalayas from Kashmir to Garhwal, between 1200 to $3000 \mathrm{~m}$.

Properties and Action: Rasa is Tikta, Guna are Laghu, Snigdha, Virya is Usna (hot), Vipaka is Katu, Karmaare Kaphahara, Vatahara, Dustavranasodhaka.

Important Formulation: Khadirarista, Dasamulrista, Devadarvarista, Mrtasanjivanisura, Karpuradyarka, PramehamihiraTaila, CandanadiChurna, SudarsanaChurna, Narayana Taila, PradarantakaLauha, VataraktanakaLauha, MahavisagarbhaTaila.

Therapeutic Uses: Sotha, Jvara, Krmi, Kandu, Pinasa, Vibandha, Adhamana, Tandra, Hikka, Prameha, Kasa, Kustha, Amavata, Raktavikara, Sutikaroga.

\section{PUSHKARA}

Botanical Name: Inula racemosa

Family: Asteraceae

Description: Puskara consists of dried root of Inula racemosa, a stout herb, 0.5 to $1.5 \mathrm{~m}$ high, mostly found in Western Himalayas up to $2600 \mathrm{~m}$.

Properties and Action.Rasa isKatu, Tikta, Gunais Laghu, Viryais Usna, Vipaka is Katu Karma is Kaphavatajt.

Important Formulations: KankayanaGutika, Kumaryasava, Mahanarayana Taila, Manasamitravaaka, Dasamularista, Lodhrsaava, RasnadiKvathaChurna.

Therapeutic Uses: Aruchi, Adhmana, Hikka, Jvara, Kasa, Swasa, Parsvashula, sopha(swelling)

HARIDRA

Botanical Name: Curcuma longa
Family : Zingiberaceae

Description: Haridra consists of the dried and cured rhizomes of Curcuma longa, a perennial herb extensively cultivated in all parts of the country, the crop is harvested after 9-10 months when lower leaves turn yellow rhizomes carefully dug up with hand-picks between October-April.

Constituents- Essential oil and a colouring matter (curcumin)

\section{Properties and Action}

Rasa are Katu, Tikta, Guna is Ruksa, Virya is Usna Vipakais Katu, Karma are Krmighna, Kusthaghna, Varnya, Vishaghna, Kaphapittanut, Pramehanasaka

Therapeutic Uses: Pandu, Prameha, Vrana, Visaavikara, Kustha, Tvagroga, Sitapitta, Pinasa

\section{HARITAKI}

Botanical Name: Terminalia chebula

Family : Combretaceae

Description: It consists of the pericarp of mature fruits of Terminalia chebula, moderate-sized or the large tree found throughout India, chiefly in deciduous forests and areas of light rainfall, but occasionally also in slightly moist forests, up to about $1500 \mathrm{~m}$ elevations, throughout India, flowers appear from April, August and fruits ripen from October-January. Properties and Action: Rasa are Madhura, Amla, Katu, Tikta, Kasaya, Guna (Quality) areLaghu, Ruksa, Viryais Usna, Vipaka is Madhur and Karma are Chakshusya, Dipana, Hrdya, Medhya, Sarvadosaprasamana, Rasayana, Anulomana.

Important Formulations: Triphala Churna, TriphaladiTaila, Abhayarista, Agastya Haritaki, Rasayana, CitrakaHaritaki, DantiHaritaki, DasamulaHaritaki, Brahma Rasayana, AbhayaLavana, PathyadiLepa.

Therapeutic Uses: Sotha, Arsa, Aruci, Hrdroga, Kasa, Pandu, Prameha, Udavarta, Vibandha, Jirnajvara, Visamajvara, Siroroga, Tamakaswasa, Gulma, Udararoga.

\section{PIPPALI MULA}

Botanical Name: Piper longum

Family: Piperaceae

Description: Consists of dried, cut, stem pieces of Piper longum a slender, aromatic, creeping and per- 
ennial herb; native of the hotter parts of the country and found wild as well as cultivated extensively in Bengal and southern states.

Properties and Action: Rasa is Katu, Guna are Laghu, Ruksa, Viryais usna, Vipaka is Katu and Karma are Dipana, Kaphahara, Pchana, Rucya, Vatahara, Vatanulomana, Sulaprasamana.

Therapeutic Uses: Anaha, Gulma, Kramiroga, Udararoga, Vataroga

\section{MANDURA}

Chemically Mandura is an Iron oxide that is formed by the action of an open atmosphere on the waste part of iron. This is a very slow reaction and takes years to convert Iron into Iron oxide. Hence it has been said that naturally formed Mandura should be very old. Probably within that time limit conversion of Iron particles into Iron oxide may get completed.

Synonyms: Lohaniryasa, Ayashishta, Malodbhava, Ayoraja, Shastrachurna, Ayomala, Lohakitta, Lohamala, Lohasinhanika and Shinhan.

Significance: All these synonyms indicate that Mandura is originated from Lauha Dhatu.

Origin and Occurrence: In Rasa classics, it has been mentioned that after severe heating of Lauha on fire, when hammering is done some parts are separated. These separated parts after many years turn into Mandura. Mandura is the by-product of the metallurgical process during the extraction of Iron $(\mathrm{Fe})$ and Copper $(\mathrm{Cu})$ from their respective ores. It occurs as lumps or aggregates at the areas where smelting activity is carried out for the extraction of Iron. Iron is the main constituent of mandura followed by silica with minor amounts of $\mathrm{Cu}, \mathrm{S}, \mathrm{Pb}, \mathrm{Zn}, \mathrm{Ag}, \mathrm{Cd}, \mathrm{Au}$.

\section{According to origin:}

In most of the Rasa classics Mandura is divided into 3 types based on the type of Lauha, from which it is originated Mundakitta is reddish, heavy and unctuous (Snigdha), TikshnakittaIt is shining like Anjana (collyrium), heavy and solid (non-porous) and Kantakit$t a$ : It is the heaviest, small, solid, rough and yellowish. It gives silvery shining on cut. Mandura which is 100 or more years old is said to be best. Mandura which is 70 to 80 years old is taken as of medium quality and less than 60 years old Mandura is considered as Visha (poisonous).

Acceptable variety: Mandura which is nonporous, heavy, unctuous, hard and more than 100 years old is considered suitable for therapeutic uses.

Adverse effects management: Virechana should be done with Aragvadha-phala-majja.

Marana of Mandura: The process of making the minerals and metals into fine powder form (bhasma) by applying the required quantum of heat is known asMarana. It is most important therapeutically because Metals and minerals are therapeutically used only in the form of Bhasma. By this process Metals and minerals become in a readily absorbable form, Free from Toxicity and conversion of initial material into suitable compound occurs that can be used internally without producing any harmful effect. By subjecting it to Marana process, the unconverted Iron if present will be converted into Iron oxide compound form and then it is not likely to produce any toxic effect. In Samhitas and Nighantus and in early texts of Rasa Shastra Marana of Mandura is not found. It is used only after proper processing to make it easily assimilable. Rasa Kamdhenu, Rasa Tarangini is the classic in which Marana of Mandura is mentioned.

Therapeutic indications of Mandura Bhasma: ManduraBhasma is indicated in Shopha, Kamala, Pandu, Krimi, Arsha, Grahani, Pliharoga, Shosha, and Amavata with specific Anupana or Sahapana. It is said to be more suitable for children (Balanamatishasyate). Mandurabhasma is indicated as general Anupana for Panduroga in Yogaratnakar.

Dose: Terminologies used in Rasa Shastra texts to indicate the dose of Mandurabhasma is as followsGunja padansha - gunja dwitayai. e. $30 \mathrm{mg}-250 \mathrm{mg}$.

Anupana: For the management of various diseases, Mandura Bhasma is administered with suitable Anupana for specified diseases.

Modern chemistry: Mandura is considered as Iron rust. It is formed by the action of the open atmosphere on the waste part of iron. When ordinary iron is exposed to moist air, it becomes, coated with a reddish-brown deposit of hydrated ferric oxide called rust. Its chemical formula is $\mathrm{Fe} 2 \mathrm{O} 3, \mathrm{H} 2 \mathrm{O}$. 
Physical properties: Mandur is a rough lumpy mass, exhibits voids, black in colour and streak is also black, no cleavage, the fracture is Conchoidal, dull lustre, tenacity is Brittle but hard, transparency is opaque, hardness is 6 to 6.5 and Sp. Gr is 3to 3.8 .

\section{Chemical properties:}

Assay: Mandura should contain not less than $30 \%$ Iron $(\mathrm{Fe})$ and $30 \%$ Silica when analyzed by gravimetric method. Mandura should contain not less than $80 \%$ Fayalite $\left(\mathrm{Fe}_{2} \mathrm{SiO}_{4}\right)$ when studied through the XRD method. Mandura should not contain more than the stated limits for Arsenic (6 ppm) and Cadmium (8 ppm). It contains Copper $0.45 \%$, Zinc 50 ppm, Silver 7 ppm.

\section{Review of Accessory Material}

Gomutra: Punarnava Mandura is a Mandura preparation called Mandurakalpa prepared by Rasakriya method. another method of preparation of Mandurakalpa is KhalviyaLauha Kalpa method. Gomutra is used for both purposes.

Chemical constituents of Gomutra: Urea $\mathrm{CO}$ $\left(\mathrm{NH}_{2}\right)_{2}$, Uric Acid $\left(\mathrm{C}_{5} \mathrm{H}_{4} \mathrm{~N}_{4} \mathrm{O}_{3}\right)$, Nitrogen $\left(\mathrm{N}_{2}\right)$, Sulphur $(\mathrm{S})$, Copper $(\mathrm{Cu})$, Iron $(\mathrm{Fe})$, Sodium $(\mathrm{Na})$, Potassium (K), Phosphate (P), Ammonia $\left(\mathrm{NH}_{3}, \mathrm{NH}_{4}\right)$, Manganese $(\mathrm{Mn}), \quad$ Calcium $(\mathrm{Ca}), \quad$ Formic acid $(\mathrm{HCOOH})$, Aurum Hydroxide $(\mathrm{AuOH})$.

\section{DISCUSSION}

The present study was planned to assess the efficacy of Punarnava Mandura in Pandu roga. Mandura Bhasma which is one of the good Haemetinic proved by various research works (experimental and clinical) is the main ingredient of this formulation. Punarnava Mandura is a very well-known drug by its "Raktajanya" property mentioned by Acharya Charaka. Furthermore, no clinical work has been reported on Punarnava Mandura in this department, besides strong classical references. Based on this, the reference regarding this in "Bhaishajya Ratnavali" was assessed for the preparation of this formulation used for the management of Pandu clinically. Pharmaceutics) emphasis has been given to work on some Bhasma based preparations because Bhasmas are the basic and unique preparation of Rasa Shastra having good therapeutic efficacy and longer self-life in comparison to the herbal dosage form. Preparations having Bhasma as an ingredient is better absorbed in the body tissues and have better therapeutic efficacy. These are called herbomineral preparation. The main aim of the present study is that most of the population of India, and the world, in different age groups, including both sexes are suffering from Pandu Roga (Iron deficiency anaemia). There are large numbers of Iron preparations available in Modern medicine having the ferrous form of iron, but most of these cause side effects like nausea, vomiting, constipation etc. To overcome these problems patients, need to take such type of Ayurvedic preparation which should be highly effective in curing the above disease, quick in action, longer self-life, better palatability as well as cost-effective.

\section{CONCLUSION}

Acharya Charaka has described various formulations for the treatment of Pandu Roga; most of these are "Lauha" preparations. Mandura is known as Lauha Kitta and Bhaishajya Ratnavali states that if lauha is not available, Mandura can be taken as an alternative. Punarnava Mandura is one of the Herbomineral preparations having Mandura as an ingredient, indicated for pandu roga. In the present work, Punarnava Mandura was prepared by the standard method. To analyse its nature, structure, and particle size, elements present in the compound and chemical constituents present in herbal drugs, analytical evaluation was planned, and a clinical study was done to see the therapeutic effect on Pandu roga patients. So, there are descriptions of multiple drugs which are very effective in iron deficiency anaemia.

\section{REFERENCES}

1. Datta GK.et al. Antiulcerogenic activity of Shatavari Mandura- an Ayurvedic herbomineral preparation, Indian J Exp Biol. 2002; 10:1173-7.

2. Gupta Kaviraj Atridev. Vrudda Vagbhata - AstangaSangra. Krishana das Academy, Varanasi,1993; $2: 22$. 
3. Prof, P.V. Sharma -Dravya Guna Vighynanm vol-2, published by Choukambha Barathi Academy, Varanasi, 16th edition 1995; 2:237.

4. Comparative study of Nishalohavati and Navayaslohavati in the management of panduroga. KC-GAAC, Ahmedabad-GAU, Jamnagar, 2008.

5. Patel Bhavesh H, Comparative PharmaceuticoPharmacoclinical Study of Kasis Bhasma (Prepared by three Different Methods) w.s.r. to its effect On Pandu Roga (Iron Deficiency Anaemia) IPGT\&RA, GAU, Jamnagar.2006.

6. O.P. Ghai, Piyush Gupta, V.K. Paul, Essential Pediatrics by, published by CBS publishers, 6th edition 2005.

7. Akman M, et.al. The effects of iron deficiency on infants' developmental test performance. Acta Paediatr, 2004; 10:1391-6.

8. Fauci A. S. et.al. Harrison s Principles of Internal Medicine, The McGraw Hill Companies, New York, 1998; 1: 640, 641.

9. Nadakarni KM. Indian Materia Medica, 3 rd Edition, Popular Prakashan, Bombay 1893; 2:634.

10. Jyothy KB. A clinical study on the efficacy of Dhatryarista in Pandu w.s.r. to IronDdeficiency Anaemia.Rajeev Gandhi University of health sciences, Karnataka Bangalore.2009.

11. Sarkar P.K. A Comparative PharmaceuticoPharmacoclinical Study of LauhaBhasma and ManduraBhasma W.S.R. To Its Pandu- Hara Effect-RS \& BK-IPGT\&R, Jamnagar, Gujarat, Joshi Damodara. Lohavijnaniyam. Ist Edition, Chaukhamba Sanskrit Bhawan chowk Varanasi 1998; 9.4: 48-50.

12. Harrison's. Principles of Internal medicine, $18^{\text {th }}$ Edition. McGrew-HillEurope2011; 1: 846.

13. Shastri-Kashinath. Rasatarangini, Motilala Banarasi Das, Varanasi, 11th Edition, 1979; 39.

14. Trikamaji Yadava ji. Acharya-Rasamritam, MotilalaBanarasi Das, Varanasi, 1979; 104: 24.

15. Shastri Kashinath and Cathurvedi Gorakhanath. Charaka SamhitaVidyotini Hindi commentary, 16th Edition, Chaukhamba Bharati Academy, 1989; 11.

16. MC Graw Hill. Harrison's principles of internal medicine, 13th edition, Health profession division 1992; 2 .

17. Recommendations to Prevent and Control Iron Deficiency in the United States. MMWR 1998; 47; 5 .

18. Vagbhata - Astanga Hridaya with Sarvanga Sundara commentary of Arunadutta and Ayurveda
19. Rasayana of Hemadri. Choukambha Surabharathi Prakashana, Varanasi, Reprint 2002; 21.

20. Das srinageen, Shahchhaganlal, rasavaidhya, B. Jain. Bharat Bhaishajya Ratnakar rasa. New, Delhi. 197 9; 3:417-418.

21. Bhaishjya Ratnavali, Pandu rogachikitsa Prakarana, Ist Edition, 2015;1: 65-67.

22. Mishra Gulraj Sharma. Rasa Kamdhenu Shuladhikara. choukhbha orientalia, Varanasi.

2014; 1:178-179.

23. Kumar Praveen, thesis, "Vachadi Upanaha and Vachadi Ghana vati in SandhigataVata w.s.r. to Osteoarthritis" Department of Pancha Karma, IPGT\&R, Jamnagar, Gujarat, 2005.

24. Sharma PV. Sushruta Samhita, Ist Edition Chaukhambha Bharati Academy Varanasi 2005.

25. Anonymous, Ayurvedic Formulary of India, Mandura Kalpa, Department of AYUSH, $2^{\text {nd }}$ Edition, Part 1, Ministry of Health and Family Welfare, Government of India, 2003.

26. Anonymous, Drugs and Cosmetics (Sixth Amendment) Rules, 2012 Ministry of Health and Family Welfare (Department of AYUSH.

27. Mohan Harsh. pathology, 6th Edition jaypee brothers' medical publishers, Ansari Road Daryaganj, New delhi.2010.

28. Amarkosha Purvakhand, 5-13.

29. Pharmacopia of India 3: 213-214.

30. Ayurvedic Pharmacopia of India api, 3: 129-130.

31. Ayurvedic Pharmacopia of India api 3:115-117.

\section{Source of Support: Nil \\ Conflict of Interest: None Declared}

How to cite this URL: Chhaya Gupta $\mathcal{L}$ Sushma Tiwari $\mathcal{A}$ Scientific Drug Review Onpunarnava Mandur. International Ayurvedic Medical Journal \{online\} 2021 \{cited November 2021\} Available from: http://www.iamj.in/posts/images/upload/2789_2796.pdf 